\title{
Reliability analysis of hanger shot blast KAZO machine in foundry plant
}

\author{
Rinaldi Sam Prabowo ${ }^{1, *}$, Priyo Agus Setiawan ${ }^{2}$, Anda Iviana Juniani ${ }^{2}$, Wiediartini ${ }^{2}$, Ika \\ Erawati $^{2}$ \\ ${ }^{1}$ Student, Safety Engineering, Marine Engineering Departement, Shipbuilding Institute of Polytechnic \\ Surabaya, 60111 Surabaya Indonesia \\ ${ }^{2}$ Marine Engineering Departement, Shipbuilding Institute of Polytechnic Surabaya, 60111 Surabaya \\ Indonesia
}

\begin{abstract}
In a metal casting industry, Hanger Shot Blast KAZO machine plays a very vital role for blasting. The downtime equipment data for the last five years, 2013 to 2017, shows that the hanger shot blast KAZO is the machine which frequently encounters downtime with the number of 503,75 hours. As the only blasting machine with 2 (two) tons of load capacity, the issues of hanger shot blast KAZO affect to the targeted production process of company. Moreover, it increases risk of safety for the workers surround the machine. The purpose of this current research is to find out the reliability value of the item/ component of hover shot blast KAZO machine using Reliability Analysis method. The malfunction of its component is reviewed by FMEA (Failure Mode and Effect Analysis). While the risk assessment is obtained from RPN (Risk Priority Number) calculation - MTTF value and reliability value $R(t)$. The result of this current study found that there are 21 malfunctions on hanger shot blast KAZO machine. MTTF analysis shows the highest MTTF value is 9195,324 hours for bearing impeller component and the lowest is 3498,997 hours for motor components. Meanwhile, reliability analysis shows that the largest reliability value with 0.999915 is encountered by motor contactor of crane, while with a value of 0.26385 , hanger rotator motor contactor component encountered the lowest reliability value.
\end{abstract}

\section{Introduction}

Every year, the needs industry of foundry, both domestic and overseas industries which run in the field such railway, mining, and process, are mostly provided by foundry field with12.800 tons capacity. The process of this industry is supported by induction furnace and arc furnace as the main engine, and shot blasting, heat treatment and others as the auxiliary engine. The largest needs supplier in the production process on the foundry plan is performed by Hanger Shot Blast KAZO machine. The downtime equipment data for the last five years, 2013 to 2017, shows that the hanger shot blast KAZO is the machine which frequently encounters downtime with the number of 503,75 hours. One of the most frequently

\footnotetext{
* Corresponding author: andahome@gmail.com
} 
breakdown is the worn-out bearing impeller. Though, the blasting process will keep running if the breakdown only in one bearing impeller. For this reason, reliability analysis is very essential to overcome the issues or cases of hanger shot blast KAZO on foundry plan. The reliability analysis analyses the function of component, types of damage, damage caused effect, and also the reliability components of machine on hanger shot blast KAZO.

\section{Methodology}

\subsection{FBD (Functional Block Diagram)}

A description of system is required to know the components on the system and how the components work due to the function. The definition and reference of how determining the preventive maintenance activities are referred to the function of equipments data and how it operates (John Moubray, 1997). The benefits of a description of system are stated as below:

1. As the basis information of system on design and operation which is used as reference to conduct the future preventive maintenance actions.

2. The complete knowledge of system can be obtained.

3. Play an important role in the process identification of operating parameters causing system failure.

\subsection{FMEA (Failure Mode and Effects Analysis) and RPN (Risk Priority Number)}

Failure Mode and Effects Analysis (FMEA) is considered as one of the systematic methods used to analyze failures. FMEA involves many observations on components, assemblies, and subsystems to identify the possibility of failure, and also the causes and effects of each failure. For each component, any form of failure and its effect on a system will be written on the FMEA form.

\subsection{RPN (Risk Priority Number)}

Risk Priority Number (RPN) is a technique used to analyze risk by connecting potential problems identified in Failure Mode and Effect Analysis (FMEA). RPN value is obtained by using the following formula:

$\mathrm{RPN}=$ Severity $\mathrm{x}$ Occurrence $\mathrm{x}$ Detection

The result of RPN value indicates the level of importance to the attention given to the area/ component contained in the system.

\subsection{Reliability Probability Distribution}

The MTTF (Mean Time To Failure) value is obtained using several formulas, depending on the distribution type on the data. Some common distributions used to calculate the reliability of equipments are shown as below:

1. Exponential Distribution

$\mathrm{MTTF}=1 / \lambda$

2. Weibull Distribution

For weibull distribution of 2 parameters:

$\mathrm{MTTF}=\eta \Gamma(1+1 / \beta)$ 
For weibull distribution of 3 parameters:

$\mathrm{MTTF}=\gamma+\eta \Gamma(1+1 / \beta)$

3. Lognormal Distribution

$$
\mathrm{MTTF}=\operatorname{Exp}(\mu+\sigma 2 / 2)
$$

4. Normal Distribution

$$
\mathrm{MTTF}=\mu
$$

5. Reliability Function

$R(t)=f(t) d t=e^{-(t / \eta) \beta}$

In which:

$\mathrm{R}=1$ (item/ component can perform its function properly)

$\mathrm{R}=0$ (item/ component cannot perform its function properly)

$\mathrm{R}=0.8$ (item/ component can perform its function $80 \%$ well)

\section{Result and Discussion}

Data processing is conducted by creating FBD (Functional Block Diagram), failure analysis using FMEA (Failure Mode and Effects Analysis), maintenance policy, and maintenance interval time.

\subsection{FBD (Functional Block Diagram)}

Figure 1 below describes the functional flow of the item/ component of the hanger shot blast KAZO machine on foundry plant

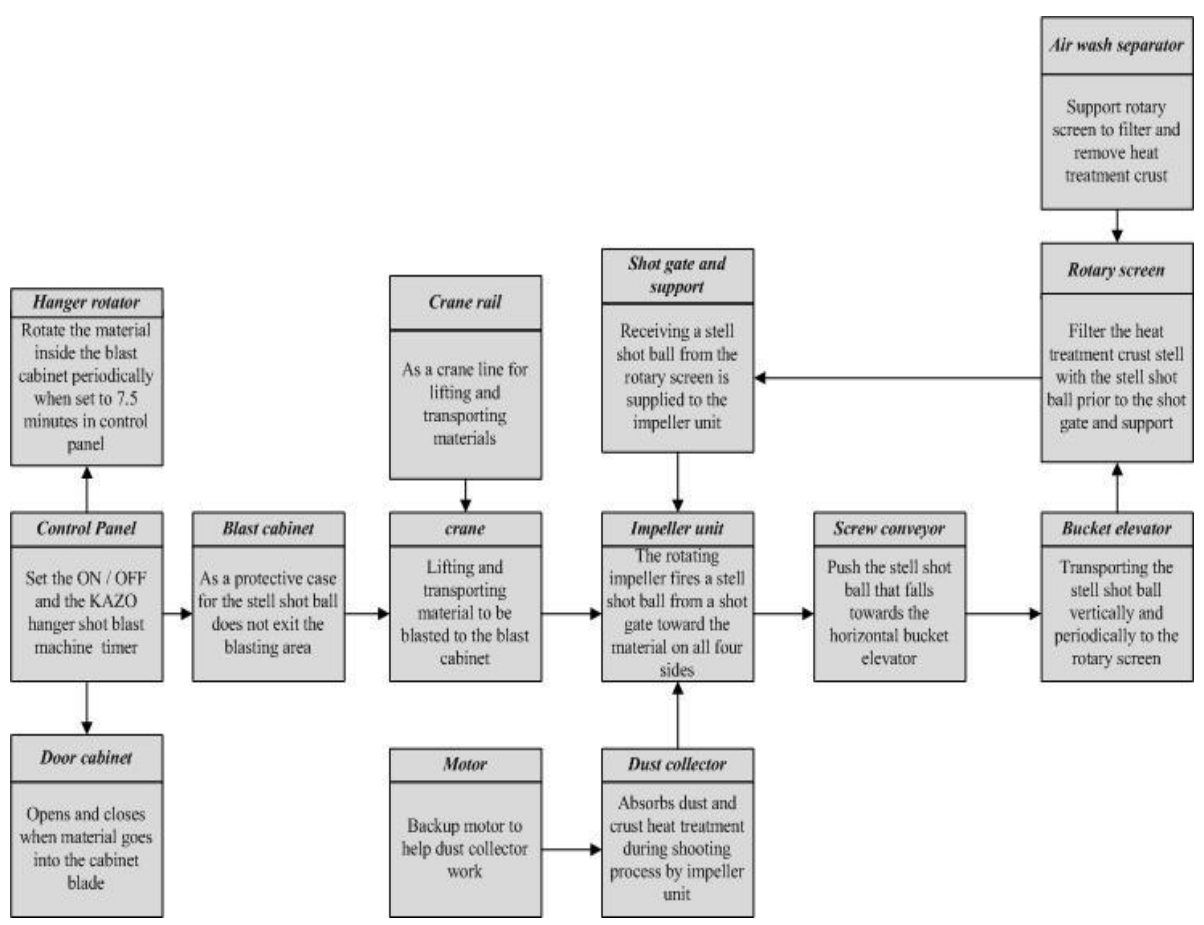

Fig. 1. Block Diagram Function 


\subsection{Failure Mode and Effect Analysis}

FMEA is used to identify failures that occur in the components of the hanger shot blast $\mathrm{KAZO}$. After the failure of each component is analyzed, the value of RPN is then determined. Table 1 below shows the FMEA table of one of the components on hanger shot blast KAZO, that is impeller and screw conveyor.

Table 1 FMEA

\begin{tabular}{|c|c|c|c|c|c|c|c|c|c|c|c|c|}
\hline \multicolumn{6}{|c|}{ System : Foundry plant } & \multirow{2}{*}{\multicolumn{7}{|c|}{ Date: }} \\
\hline \multicolumn{6}{|c|}{ Sub-System: Hanger Shot blast KAZO } & & & & & & & \\
\hline No & Equipment & & Function & & $\begin{array}{l}\text { Inctional } \\
\text { Failure }\end{array}$ & \multicolumn{2}{|r|}{$\begin{array}{c}\text { Failure } \\
\text { Mode }\end{array}$} & $\begin{array}{l}\text { Failure } \\
\text { Effects }\end{array}$ & $\mathbf{S}$ & $\mathbf{O}$ & D & RPN \\
\hline \multirow[t]{3}{*}{1.} & \multirow[t]{3}{*}{ Impeller unit } & \multirow[t]{3}{*}{1} & \multirow{3}{*}{$\begin{array}{l}\text { Rotating } \\
\text { compone } \\
\text { nt to fire } \\
\text { steel shot } \\
\text { ball }\end{array}$} & \multirow[t]{3}{*}{ A } & \multirow{3}{*}{$\begin{array}{l}\text { Cannot fire } \\
\text { steel shot } \\
\text { ball } \\
\text { maximally } \\
\text { toward the } \\
\text { blasting } \\
\text { object }\end{array}$} & 1 & $\begin{array}{l}\text { Broken } \\
\text { Blade } \\
\text { Impeller }\end{array}$ & \multirow{3}{*}{$\begin{array}{l}\text { steel shot } \\
\text { ball } \\
\text { leaking } \\
\text { on HSB } \\
\text { machine' } \\
\text { s cover }\end{array}$} & 3 & 5 & 1 & 15 \\
\hline & & & & & & 2 & $\begin{array}{l}\text { Leaking } \\
\text { Liner }\end{array}$ & & 1 & 4 & 2 & 8 \\
\hline & & & & & & 3 & $\begin{array}{l}\text { Bearing } \\
\text { pecah }\end{array}$ & & 1 & 4 & 2 & 8 \\
\hline
\end{tabular}

\subsection{Determination of Distribution}

Weibull ++ version 6 software is applied to assess and process the downtime data in determining the type of distribution on the failures. The result of the assessment is aimed to obtain the alternative distribution in rank sequence, in which the best rank distribution will be selected. In addition, the output of the software will result the parameter distribution that can be used to determine the interval time of the broken component (MTTF) and its reliability.

Table 2 Distribution Parameter Result

\begin{tabular}{|c|c|c|c|c|}
\hline No & Equipment & Sub equipment & $\boldsymbol{\beta}$ & $\eta$ \\
\hline \multirow{3}{*}{1} & \multirow{3}{*}{ impeller } & blade impeller & 5,6941 & 9402,779 \\
\hline & & liner & 3,7714 & 4864,188 \\
\hline & & bearing & 8,4313 & 9705,852 \\
\hline \multirow{3}{*}{2} & \multirow{3}{*}{ screw conveyor } & fuse & 7,9843 & 9543,943 \\
\hline & & gear screw & 4,7336 & 9965,852 \\
\hline & & sproket & 7,7159 & 5009,752 \\
\hline \multirow[t]{2}{*}{3} & \multirow{2}{*}{ bucket elevator } & belt & 2,5835 & 5418,992 \\
\hline & & fuse & 7,033 & 6069,204 \\
\hline \multirow[t]{2}{*}{4} & \multirow{2}{*}{ rotary screen } & rantai & 15,3404 & 5793,614 \\
\hline & & bearing rotary & 2,0323 & 7641,488 \\
\hline 5 & shot gate and support & hose shot gate & 2,8823 & 4340,899 \\
\hline \multirow[t]{2}{*}{6} & \multirow{2}{*}{ hanger rotator } & bearing hanger rotator & 1,9482 & 4940,449 \\
\hline & & contactor motor & 2,0348 & 4689,773 \\
\hline
\end{tabular}


The parameters resulted from distribution above are used to calculate the MTTF (Mean Time To Failure) value and to analyze the reliability of the hanger shot blast KAZO machine's item/ component in foundry plant.

\subsection{MTTF calculations}

The calculation below determines the result of MTTF (Mean Time To Failure) calculation taken from the blade impeller of hanger shot blast KAZO machine's components.

$$
\begin{aligned}
\mathrm{MTTF} & =\eta \Gamma(1+1 / \beta) \text { Weibull } 2 \\
& =9402,779 \Gamma(1+1 / 5,6941) \\
& =9402,779 \Gamma(1,17) \\
& =9402,779(0,92670) \\
& =8713,55 \mathrm{jam}
\end{aligned}
$$

\begin{tabular}{|c|c|c|c|c|}
\hline No & Equipment & Failure Mode & Distribution & MTTF \\
\hline \multirow[t]{4}{*}{1.} & \multirow[t]{4}{*}{ Impeller unit } & blade impeller pecah & Weibull 2 & 8713,5553 \\
\hline & & liner impeller bocor & Weibull 2 & 4507,64283 \\
\hline & & \multirow{2}{*}{$\begin{array}{c}\text { Bearing impeller } \\
\text { pecah }\end{array}$} & Weibull 2 & 9195,32456 \\
\hline & & & & \\
\hline
\end{tabular}

See table Gamma function $\Gamma(1,17)=0,92670$

Table 3 MTTF

\subsection{Calculation of Reliability Value of Component $\mathbf{R}(\mathbf{t})$}

The reliability value of the component provides an opportunity reliability data of a component in the interval of $t$ (time) hour. The result of reliability calculation at $t=5400$ hours shows the value of blade impeller of hanger shot blast KAZO machine as follow:

$\mathrm{R}(\mathrm{t}) \quad=\mathrm{e}^{-(\mathrm{t} / \mathrm{\eta}) \mathrm{\beta}}$

$$
\begin{aligned}
& =\mathrm{e}^{-(5400 / 9402,77) 5,69} \\
& =0,958379
\end{aligned}
$$

While the Figure 2 below shows the graphic of component reliability 


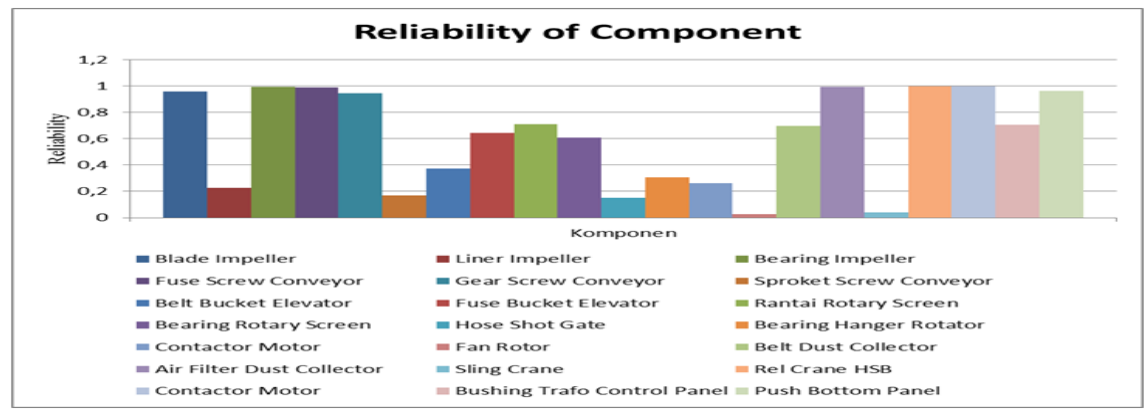

Fig. 2. Reliability Component

\section{Conclusion}

Based on the result data on the discussion above, this current research indicates:

1. FMEA analysis (Failure Mode and Effect Analysis) shows that there are 21 forms of failure (failure modes). The result of risk assessment by risk priority number (RPN) given in FMEA (Failure Mode and Effect Analysis) shows that there are 3 (three) components with high RPN value.

2. MTTF (Mean Time to Failure) analysis of the hanger shot blast KAZO machine's component/ item indicates that the highest MTTF value or the one which most rarely damaged is on the bearing impeller component, with the value of 9195,324 hours. While the lowest MTTF value or the one which frequently damaged is the motor item/ component with the value of 3498.997 hours.

3. The result of MTTF calculation shows that the highest the MTTF value of a component, the most rarely the equipments encounter damage or failure. Otherwise, the equipment will frequently encounter damage if its MTTF value of the components is low.

4. The result of reliability analysis of the item/ component of the hover shot blast KAZO machine at $t=5400$ hours indicates that the motor contactor item/ component on crane has the highest $\mathrm{R}(\mathrm{t})$ value of 0.999915 . While the motor contractor's component of hanger rotator has the lowest $R(t)$ value with a value of 0.26385 .

\section{References}

1. R. P. Lukodono, et al. Tesis Magister tidak dipublikasikan, Program Magister Teknik Mesin, Program Magister dan Doktor Fakultas Teknik, Universitas Brawijaya, Malang (2013)

2. J. Moubray. Industrial Press Inc. Madison Avenue, New York (1997)

3. H. Pranoto. 1st ed. Jakarta: Mitra Wacana Media dengan Universitas Mercubuana (2015)

4. Yuhelson, dkk 2 (2010) 